\title{
Molecular Aspects of Secretory Granule Exocytosis by Neurons and Endocrine Cells ${ }^{a}$
}

\author{
MANFRED GRATZL \\ Abteilung Anatomie und Zellbiologie \\ Universität Ulm \\ 89069 Ulm, Germany
}

\section{INTRODUCTION}

Neuronal communication and endocrine signaling are fundamental for integrating the function of tissues and cells in the body. Hormones released by endocrine cells are transported to the target cells through the circulation. By contrast, transmitter release from neurons occurs at specialized intercellular junctions, the synapses. Nevertheless, the mechanisms by which signal molecules are synthesized, stored, and eventually secreted by neurons and endocrine cells are very similar.

Neurons and endocrine cells have in common two different types of secretory organelles, indicating the presence of two distinct secretory pathways. The synaptic vesicles of neurons contain excitatory or inhibitory neurotransmitters, whereas the secretory granules (also referred to as dense core vesicles, because of their electron dense content) are filled with neuropeptides and amines. In endocrine cells, peptide hormones and amines predominate in secretory granules. The function and content of vesicles, which share antigens with synaptic vesicles, are unknown for most endocrine cells. However, in B cells of the pancreatic islet, these vesicles contain GABA, which may be involved in intrainsular signaling. ${ }^{1}$

Exocytosis of both synaptic vesicles and secretory granules is controlled by cytoplasmic calcium. However, the precise mechanisms of the subsequent steps, such as docking of vesicles and fusion of their membranes with the plasma membrane, are still incompletely understood. This contribution summarizes recent observations that elucidate components in neurons and endocrine cells involved in exocytosis. Emphasis is put on the intracellular aspects of the release of secretory granules that recently have been analyzed in detail.

\section{SECRETORY ORGANELLE MEMBRANE PROTEINS AND THEIR COUNTERPARTS AT THE CELL MEMBRANE}

A variety of membrane proteins, exposed on the cytoplasmic surface of secretory organelles, have been suggested to participate in exocytosis. For example, GTPbinding proteins ( $G$ proteins) have been found in membranes of secretory granules ${ }^{2-4}$ and synaptic vesicles. ${ }^{5}$ There are several reasons to believe that $G$ proteins are involved in docking and/or fusion of secretory granules with the plasma membrane. In particular, the effect of GTP and its analogues on exocytosis by chromaffin cells ${ }^{6-8}$ argues for the participation of these proteins in exocytosis. In nerve terminals, synaptic vesicles are used for several cycles of exocytosis, and $G$ proteins control

${ }^{a}$ Work in the author's laboratory was supported by the Deutsche Forschungsgemeinschaft. 
cycling and docking of synaptic vesicles, ${ }^{9,10}$ possibly together with additional proteins, such as rabphilin, ${ }^{11}$ a member of the synaptotagmin family (see below).

Synaptotagmin was the first membrane protein detected in both synaptic vesicles and secretory granules. ${ }^{12}$ Its presence in chromaffin granules and in neurohypophysial granules ${ }^{13}$ has recently been confirmed. ${ }^{14}$ Synaptotagmin is characterized by several interesting properties. Its ability to bind calcium ions in the presence of phospholipids suggests a role as a calcium sensor during exocytosis. ${ }^{15}$ Moreover, synaptotagmin interacts with syntaxin, a synaptic protein implicated in docking of synaptic vesicles to the plasma membrane. ${ }^{16.17}$ In addition, synaptotagmin binds to the cytoplasmic domain of neurexin, the receptor of alpha latrotoxin, a toxin from a spider venom that activates transmitter release.$^{18,19}$ Finally, peptides corresponding to cytoplasmic domains of synaptotagmin are inhibitory to exocytosis of both synaptic vesicles and secretory granules. ${ }^{20.21}$ Taken together, these data are strong evidence for the involvement of synaptotagmin and its partners in exocytosis of the two major secretory organelles of neurons and endocrine cells. Moreover, the interaction of synaptotagmin with syntaxin and calcium channels at the plasma membrane would place these complexes into a favorable position at the site of calcium influx that triggers exocytosis. . $^{16,22-24}$

Synaptophysin is a member of a family of secretory organelle membrane proteins. With one exception, ${ }^{25}$ the known members of the synaptophysin family ${ }^{26}$ and synaptoporin ${ }^{27.28}$ are strictly confined to neurons and endocrine cells. ${ }^{29,30}$ At present, it is not clear whether members of this protein family exist in secretory granule membranes as well as in synaptic vesicles. ${ }^{14.31-33}$ Synaptophysin, which interacts with the plasma-membrane component, physophilin, ${ }^{34}$ is involved in pore formation during exocytosis, ${ }^{35}$ and antibodies to synaptophysin interfere with transmitter secretion in neuromuscular synapses. ${ }^{36}$

Synaptobrevins (also referred to as vesicle-associated membrane proteins, VAMPs), are neural isoforms of ubiquitous intracellular vesicle membrane protein, named cellubrevin. ${ }^{37-39}$ Recently, two proteins of the plasma membrane, syntaxins (also referred to as HPC-1) and the synaptosomal-associated protein, SNAP-25, have been uncovered as possible partners of synaptobrevins. ${ }^{40}$ Because injection of an antibody to syntaxin or of different portions of the cytoplasmic domain of syntaxin inhibits exocytosis of secretory granules from pheochromocytoma cells, syntaxins obviously play an important role in secretion. ${ }^{41}$ Further evidence for the participation of synaptobrevins, syntaxins, and SNAP-25 in exocytosis will be discussed below.

\section{TARGETS OF TETANUS AND BOTULINUM TOXINS}

Botulism is caused by a toxin produced in patients infected with Clostridium botulinum or by ingestion of food contaminated with the toxin. Blockade of acetylcholine release at motor end plates by botulinum toxin results in a progressive flaccid neuromuscular paralysis, the hallmark of the disease. By contrast, the clinical manifestations of tetanus, generalized spasms, are caused by a preferential blockade of transmitter release from glycinergic inhibitory interneurons in the spinal cord by tetanus toxin, produced by Clostridium tetani in wounds. It turned out that the clostridial neurotoxins are excellent tools for deciphering the molecular mechanisms of exocytosis.

Application of tetanus toxin and botulinum $A$ toxins to intact synaptosomes and neurohypophysial nerve endings prevented exocytosis of synaptic vesicles and secretory granules. ${ }^{42.43}$ Thus, the neurotoxins inhibit both secretory pathways charac- 
terized by these secretory organelles. Moreover, injection of tetanus toxin into chromaffin cells revealed that clostridial neurotoxins act from within the cells. ${ }^{44}$ In addition, permeabilization studies established that the neurotoxins inhibit exocytosis at a step downstream the elevation of intracellular calcium. ${ }^{45,46}$ Cleavage of the constituent light and heavy chains of clostridial neurotoxins is a prerequisite for the inhibition of exocytosis. ${ }^{44.47}$ Then, the light chains of the neurotoxins alone are active within neurons and endocrine cells. ${ }^{48-55}$ Thus, the mechanism of the neurotoxins' action involves endocytotic internalization of the disulfide-linked light and heavy chains, reductive chain separation, and translocation of the light chains from the endosome compartment to the cytoplasm. Finally, the light chain inhibits calciumtriggered exocytosis, which includes vesicle docking and fusion.

Although the tetanus toxin light chain when applied within neurohypophysial nerve terminals or adrenal chromaffin cells completely inhibits exocytosis, the light chain of botulinum $A$ toxin blocks exocytosis only in part. ${ }^{47.48,52}$ This observation is in accordance with recent findings that tetanus toxin and the different types of botulinum toxins attack different membrane proteins of secretory organelles or the plasma membrane, which have been suggested to participate in the release of neurotransmitters (see above). SNAP-25, linked to the plasma membrane through fatty acids, is cleaved by botulinum $A$ and botulinum $E$ toxin. ${ }^{56,57}$ In addition syntaxin, a transmembrane protein of the plasma membrane, is a substrate of botulinum $\mathrm{C} 1$ toxin. ${ }^{58}$ On the other hand, tetanus toxin cleaves synaptobrevin $2,{ }^{59-61}$ a well-conserved synaptic vesicle membrane protein. In addition, synaptobrevins can be cleaved by botulinum B, D, and F toxins..$^{57,61,62}$ Interestingly, synaptobrevins, SNAP25 , and syntaxins, together with soluble proteins, are components of a suggested docking and fusion complex..$^{40} \mathrm{~A}$ model of the exocytosis machinery and the attack sites for clostridial neurotoxins is shown in Figure 1.

\section{FUNCTIONAL ANALYSIS OF NEUROTOXIN TARGETS}

Blockade of acetylcholine release from Aplysia neurons by tetanus toxin is delayed by peptides spanning the cleavage site of synaptobrevin $2,{ }^{61}$ and inhibition of glutamate release from synaptosomes is paralleled by cleavage of synaptobrevin. ${ }^{59}$ Moreover, in neurohypophysial nerve terminals, the inhibition of vasopressin release by the tetanus toxin light chain is completely abolished by peptides spanning the cleavage sites of synaptobrevin 1 or synaptobrevin $2 .{ }^{63}$ Taken together, these data imply that synaptobrevins are centrally involved in exocytosis of synaptic vesicles and secretory granules from neurons.

Surprisingly, peptides that harbor the site of synaptobrevins cleaved by the tetanus toxin light chain do not prevent the action of the toxin in the endocrine adrenal chromaffin cells. ${ }^{64}$ Similarly, captopril, an inhibitor of synaptobrevin cleavage and tetanus toxin action in neurons, ${ }^{61,63}$ was ineffective in endocrine cells. ${ }^{64}$ Moreover, the absence of synaptobrevin from adrenal secretory granules ${ }^{65,66}$ indicates that, in contrast to neurons, synaptobrevins are not a functional target of tetanus toxin in the endocrine chromaffin cells.

\section{MECHANISM OF TETANUS TOXIN ACTION}

The sequences of many clostridial neurotoxins, including tetanus and botulinum A toxin, have been elucidated. ${ }^{67}$ The light chains of the neurotoxins contain a 


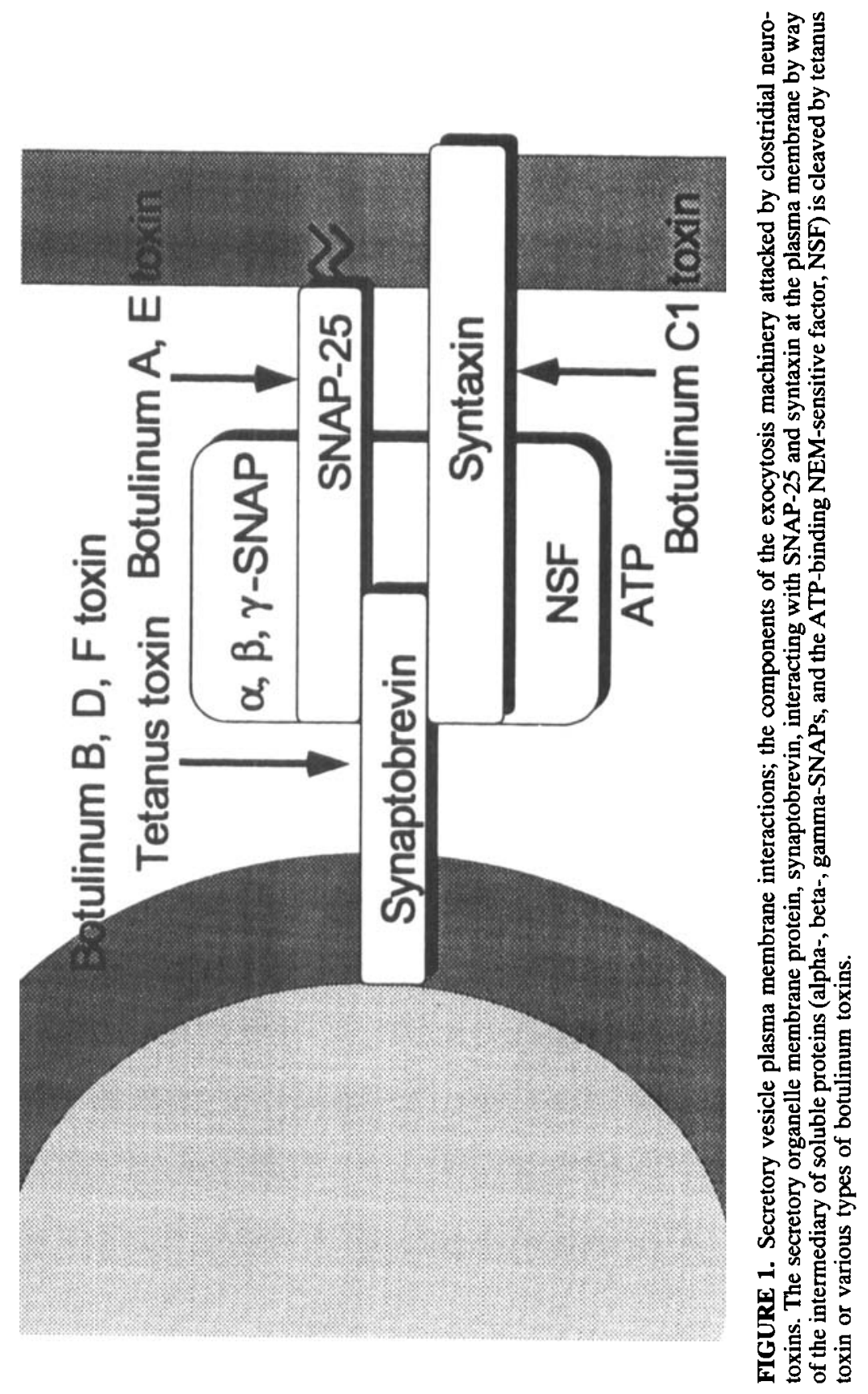


conserved domain with a pattern of histidine residues. The same motif occurs in the catalytic site of zinc-dependent peptidases. ${ }^{68}$ Several observations suggest that the light chains of clostridial neurotoxins function as peptidases and cleave their substrates in a zinc-dependent manner. Histidine-specific reagents and chelators for divalent cations abrogate the effectivity of tetanus toxin. ${ }^{60}$ Mutational modification of the histidine residues within the zinc-binding motif caused a complete inactivation of the neurotoxin when tested in permeabilized neurohypophysial nerve terminals or chromaffin cells. ${ }^{63,64}$ Moreover, selective removal of zinc from the tetanus toxin light chain by dipicolinic acid reversibly abolished its activity, although restoration of zinc yielded a fully active toxin, copper and nickel were only partly effective. By contrast, cadmium and cobalt were not effective. ${ }^{64}$ Interestingly, a similar specificity for divalent cations was observed during zinc binding studies with isolated tetanus toxin. ${ }^{69}$ Taken together, these data indicate that zinc and the conserved domain with a pattern of histidine residues constitute the active site of clostridial neurotoxins.

\section{DIFFERENTIAL EXPRESSION AND DEVELOPMENT OF THE EXOCYTOSIS MACHINERY}

As outlined in previous sections of this article, there is accumulating evidence that synaptophysins, synaptotagmins, and synaptobrevins on organelle membranes and SNAP-25, syntaxins, and neurexins at the plasma membrane are key players in exocytosis. However, deletions in the synaptotagmin genes ${ }^{70-72}$ do not completely block exocytosis in the organisms. Moreover, evoked secretion has been reported in cell lines devoid of synaptotagmin. ${ }^{73}$ In addition, the incomplete block of exocytosis by botulinum $A$ toxin, ${ }^{47,48,52}$ which cleaves SNAP-25, $, 5,57$ indicates redundancy of components of the fusion/docking components and the presence of alternate pathways of exocytosis. Finally, not all fusion/docking proteins are present in selected neurons. For example, synaptophysins, synaptotagmins, synaptobrevins, and SNAP25 show different patterns of distribution in the central nervous system. ${ }^{28.74-78}$ Thus, different types of neurons express different combinations of these proteins. During development of neurons, secretory vesicle membrane proteins are already found in outgrowing fibers and growth cones. ${ }^{79-81}$ During synaptogenesis, they become clustered in terminals when function unfolds. However, the pattern of the components of the docking/fusion machinery may change during development. For example, striatal GABAergic neurons prenatally express synaptophysin, whereas synaptoporin is the major antigen expressed postnatally. ${ }^{80}$ Developmental loss of SNAP-25 has been observed in olfactory glomeruli and other brain areas. ${ }^{82}$ Thus, nerve terminal proteins are differentially expressed in mature and developing neurons. In this way the function of the exocytotic machinery can be modulated or adjusted to the changing tasks of a neuron within the developing neuronal network.

In conclusion, it appears that the essential components involved in synaptic vesicle or secretory granule exocytosis have been identified with a variety of different techniques. However, the exact roles of the membrane proteins of the secretory organelles and of the plasma membrane of neurons and endocrine cells have yet to be delineated.

\section{ACKNOWLEDGMENTS}

The author thanks present and previous members and visitors of the Department of Anatomy and Cell Biology for valuable suggestions. 


\section{REFERENCES}

1. Thomas-Reetz, A., J. W. Hell, M. J. During, C. Walch-Solimena, R. Jahn \& P. DE CAMILI. 1993. A gamma-aminobutyric acid transporter driven by a proton pump is present in synaptic-like microvesicles of pancreatic $\beta$ cells. Proc. Natl. Acad. Sci. USA 90: $5317-5321$.

2. Doucet, J-P., S. Fournier, M. Parulekar \& J.-M. Trifarò. 1989. Detection of low molecular mass GTP-binding proteins in chromaffin granules and other subcellular fractions of chromaffin cells. FEBS Lett. 247: 127-131.

3. Burgoyne, R. D. \& A. Morgan. 1989. Low molecular mass GTP-binding proteins of adrenal chromaffin cells are present on the secretory granules. FEBS Lett. 245: 122126.

4. Darchen, F., A. Zahraoui, F. Hammel, M.-P. Monteils, A. Tavitian \& D. Scherman. 1990. Association of the GTP-binding protein Rab3A with bovine adrenal chromaffin granules. Proc. Natl. Acad. Sci. USA 87: 5692-5696.

5. Fischer von Mollard, G., G. A. Mignery, M. Baumert, M. S. Perin, T. J. Hanson, P. M. Burger, R. JaHN \& T. C. SüDHOF. 1990. Rab3 is a small GTP-binding protein exclusively localized to synaptic vesicles. Proc. Natl. Acad. Sci. USA 87: 19881992.

6. Ahnert-Hilger, G., M. Bräutigam \& M. Gratzl. 1987. Ca2+-stimulated catecholamine release from alpha-toxin permeabilized PC12 cells: Biochemical evidence for exocytosis and its modulation by protein kinase $\mathrm{C}$ and G-proteins. Biochemistry 26: 78427848.

7. Bader, M. F., J.-M. Sontag, D. Thiersé \& D. Aunis. 1989. A reassessment of guanine nucleotide effects on catecholamine secretion from permeabilized adrenal chromaffin cells. J. Biol. Chem. 264: 16426-16434.

8. Ahnert-Hilger, G., U. Wegenhorst, B. Stecher, K. Spicher, W. Rosenthal \& M. Gratzl. 1992. Exocytosis from permeabilized bovine adrenal chromaffin cells is differently modulated by GTPyS and GMPPNHP. Evidence for the involvement of various guanine nucleotide-binding proteins. Biochem. J. 284: 321-326.

9. Fischer von MOllaRd, G., T. C. Südhof \& R. JahN. 1991. A small GTP-binding protein dissociates from synaptic vesicles during exocytosis. Nature 349: 79-81.

10. Hess, S. D., P. A. Doroshenko \& G. J. Augustine. 1993. A functional role for GTPbinding proteins in synaptic vesicle cycling. Science 259: 1169-1172.

11. Shirataki, H., K. Kaibuchi, T. Sakoda, S. Kishida, T. Yamaguchi, K. Wada, M. MiYAZAKI \& Y. TAKaI. 1993. Rabphilin-3A, a putative target protein for smg p25A/rab3A p25 small GTP-binding protein related to synaptotagmin. Mol. Cell. Biol. 13: 2061-2068.

12. Matthews, W. D., L. Tsavaler \& L. F. Reichardt. 1981. Identification of a synaptic vesicle-specific membrane protein with a wide distribution in neuronal and neurosecretory tissue. J. Cell Biol. 91: 257-269.

13. Trifaròo, J.-M., S. Fournier \& M. L. Novas. 1989. The p65 protein is a calmodulinbinding protein present in several types of secretory vesicles. Neurosci. 29: 1-8.

14. Walch-Solimena, C., K. Takei, K. L. Marek, K. Midyett, T. C. Südhof, P. De CAMMILli \& R. JAHN. 1993. Synaptotagmin: A membrane constituent of neuropeptidecontaining large dense-core vesicles. J. Neurosci. 13: 3895-3903.

15. Brose, N., A. G. Petrenko, T. C. Südhof \& R. Jahn. 1992. Synaptotagmin: A calcium sensor on the synaptic vesicle surface. Science 256: 1021-1025.

16. Yoshida, A., C. Oho, A. Omori, R. Kuwahara, T. Ito \& M. Takahashi. 1992. HPC-1 is associated with synaptotagmin and omega-conotoxin receptor. J. Biol. Chem. 267: 24925-24928.

17. Bennett, M. K., N. Calakos \& R. H. Scheller. 1992. Syntaxin: A synaptic protein implicated in docking of synaptic vesicles at presynaptic active zones. Science 257 : 255-259.

18. Petrenko, A. G., M. S. Perin, B. A. Davletov, Y. A. Ushraryov, M. Geppert \& T. C. SüDHOF. 1991. Binding of synaptotagmin to the $\alpha$-latrotoxin receptor implicates both in vesicle exocytosis. Nature 353: 65-68. 
19. Hata, Y., B. Davletov, A. G. Petrenko, R. Jahn \& T. C. Sudhof. 1993. Interaction of synaptotagmin with the cytoplasmic domains of neurexins. Neuron 10: 307-315.

20. Bommert, K., M. P. Charlton, W. DeBello, G. J. Chin, H. Betz \& G. J. Augustine. 1993. Inhibition of neurotransmitter release by $\mathrm{C} 2$ domain peptides implicates synaptotagmin in exocytosis. Nature 363: 163-165.

21. Elferink, L. A., M. R. Peterson \& R. H. Scheller. 1993. A role for synaptotagmin (p65) in regulated exocytosis. Cell 72: 153-159.

22. Leveque, C., T. Hoshino, P. David, Y. Shoji-Kasal, K. Leys, A. Omori, B. Lang, O. El Far, K. Sato, N. Martin-Moutot, J. Newsom-Davis, M. Takahashi \& M. J. SEAGar. 1992. The synaptic vesicle protein synaptotagmin associates with calcium channels and is a putative Lambert-Eaton myasthenic syndrome antigen. Proc. Natl. Acad. Sci. USA 89: 3625-3629.

23. David, P., O. El Far, N. Martin-Mouto, M. F. Poupon, M. Takahashi \& M. J. Seagar. 1993. Expression of synaptotagmin and syntaxin associated with $\mathbf{N}$-type calcium channels in small cell lung cancer. FEBS Lett. 326: 135-139.

24. Oconnor, V. M., O. Shamotienko, E. Grishin \& H. Betz. 1993. On the structure of the 'synaptosecretosome.' Evidence for a neurexin/synaptotagmin/syntaxin/Ca2+ channel complex. FEBS Lett. 326: 255-260.

25. Zhong, C., D. J. Hayzer \& M. S. Runge. 1992. Molecular cloning of a cDNA encoding a novel protein related to the neuronal vesicle protein synaptophysin. Biochim. Biophys. Acta 1129: 235-238.

26. BIXBY, J. L. 1992. Identification of an alternatively spliced avian member of the synaptophysin gene family. Mol. Brain Res. 13: 339-348.

27. Knaus, P., B. Marouėze-Pouey, H. Scherer \& H. Betz. 1990. Synaptoporin, a novel putative channel protein of synaptic vesicles. Neuron 5: 453-462.

28. Marqueze-Pouey, B., W. Wisden, M. L. Malosio \& H. Betz. 1991. Differential expression of synaptophysin and synaptoporin mRNAs in the postnatal rat central nervous system. J. Neurosci. 11: 3388-3397.

29. JaHN, R. \& P. DE CAMilli. 1991. Markers for neural and endocrine cells. Membrane proteins of synaptic vesicles: Markers for neurons and neuroendocrine cells; tools for the study of neurosecretion. M. Gratzl \& K. Langley, Eds.: 25-92. VCH-Verlagsgesellschaft. Weinheim.

30. JahN, R. \& T. C. Südhof. 1993. Synaptic vesicles and exocytosis. Annu. Rev. Neurosci. 17: $216-246$.

31. Schmidle, T., R. Weiler, C. Desnos, D. Scherman, R. Fischer-Colbrie, E. Floor \& H. WINKLER. 1991. Synaptin/synaptophysin, p65 and SV2: Their presence in adrenal chromaffin granules and sympathetic large dense core vesicles. Biochim. Biophys. Acta 1060: $251-256$.

32. Schilling, K. \& M. Gratzl. 1988. Quantification of $\mathrm{p} 38$ /synaptophysin in highly purified adrenal medullary chromaffin vesicles. FEBS Lett. 233: 22-24.

33. WiedenmanN, B., H. Rehm \& M. KNIERIM. 1988. Fractionation of synaptophysin-containing vesicles from rat brain and cultured PC12 pheochromocytoma cells. FEBS Lett. 240: 71-74.

34. Thоmas, L. \& H. BeTz. 1990 . Synaptophysin binds to physophilin, a putative synaptic plasma membrane protein. J. Cell Biol. 111: 2041-2052.

35. Thomas, L., K. Hartung, D. Langosch, H. Rehm, E. Bamberg, W. W. Franke \& H. BETz. 1988. Identification of synaptophysin as a hexameric channel protein of the synaptic vesicle membrane. Science 242: 1050-1053.

36. Alder, J., Z.-P. Xie, F. Valtorta, P. Greengard \& M.-m. Poo. 1992. Antibodies to synaptophysin interfere with transmitter secretion at neuromuscular synapses. Neuron 9: $759-768$.

37. Baumert, M., P. R. Maycox, F. Navone, P. De Camilli \& R. Jahn. 1989. Synaptobrevin: an integral membrane protein of 18000 daltons present in small synaptic vesicle of rat brain. EMBO J. 8: 379-384.

38. Trimble, W. S., D. M. Cowan \& R. H. Scheller. 1988. VAMP-1: A synaptic vesicleassociated integral membrane protein. Proc. Natl. Acad. Sci. USA 85: $4538-4542$.

39. McMahon, H., Y. A. Ushraryov, L. Edelman, E. Link, T. Binz, H. Niemann, R. Jahn \& 
T. C. SüdHof. 1993. Cellubrevin: A ubiquitous tetanus-toxin substrate homologous to a putative synaptic vesicle fusion protein. Nature 364: 346-349.

40. Sollner, T., S. W. Whiteheart, M. Brunner, H. Erduument-Bromage, S. Geromanos, P. TEMPST \& J. E. Rothman. 1993. SNAP receptors implicated in vesicle targeting and fusion. Nature 362: 318-324.

41. Bennett, M. K., J. E. Garcia-Arrarás, L. A. Elferink, K. Peterson, A. M. Fleming, C. D. Hazuka \& R. H. Scheller. 1993. The syntaxin family of vesicular transport receptors. Cell 74: 863-873.

42. Mcmahon, H. T., P. Foran, J. O. Dolly, M. Verhage, V. M. Wiegant \& D. G. NichOLl.s. 1992. Tetanus toxin and botulinum toxins type A and B inhibit glutamate, y-aminobutyric acid, aspartate, and met-enkephalin release from synaptosomes. J. Biol. Chem. 267: 21338-21343.

43. Halpern, J. L., W. H. Habig, H. Trenchard \& J. T. Russell. 1990 . Effect of tetanus toxin on oxytocin and vasopressin release from nerve endings of the neurohypophysis. J. Neurochem. 55: 2072-2078.

44. Ahnert-Hilger, G., M. F. Bader, S. Bhakdi \& M. Gratzl. 1989. Introduction of macromolecules into bovine adrenal medullary chromaffin cells and rat pheochromocytoma cells (PC12) by permeabilization with streptolysin O: Inhibitory effect of tetanus toxin on catecholamine secretion. J. Neurochem. 52: 1751-1758.

45. Penner, R., E. Neher \& F. Dreyer. 1986. Intracellularly injected tetanus toxin inhibits exocytosis in bovine adrenal chromaffin cells. Nature 324: 76-78.

46. Bittner, M. A. \& R. W. Holz. 1988. Effects of tetanus toxin on catecholamine release from intact and digitonin-permeabilized chromaffin cells. J. Neurochem. 51: 451456.

47. Stecher, B., M. Gratzl \& G. Ahnert-Hilger. 1989. Reductive chain separation of botulinum $A$ toxin-a prerequisite to its inhibitory action on exocytosis in chromaffin cells. FEBS Lett. 248: 23-27.

48. Stecher, B., U. Weller, E. Habermann, M. Gratzl \& G. Ahnert-Hilger. 1989. The light chain but not the heavy chain of botulinum $A$ toxin inhibits exocytosis from permeabilized adrenal chromaffin cells. FEBS Lett. 255: 391-394.

49. Ahnert-Hilger, G., U. Weller, M.-E. Dauzenroth, E. Habermann \& M. Gratzl. 1989. The tetanus toxin light chain inhibits exocytosis. FEBS Lett. 242: 245-248.

50. Bittner, M. A., W. H. HABIG \& R. W. Holz. 1989. Isolated light chain of tetanus toxin inhibits exocytosis: Studies in digitonin-permeabilized cells. J. Neurochem. 53: 966968.

51. Bittner, M. A., B. R. GasGupta \& R. W. Holz. 1989. Isolated light chains of botulinum neurotoxins inhibit exocytosis. J. Biol. Chem. 264: 10354-10360.

52. Dayanithi, G., G. Ahnert-Hilger, U. Weller, J. J. Nordmann \& M. Gratzl. 1990. Release of vasopressin from isolated permeabilized neurosecretory nerve terminals is blocked by the light chain of botulinum $A$ toxin. Neurosci. 39: 711-715.

53. Dayanithi, G., U. Weller, G. Ahnert-Hilger, H. Link, J. J. Nordmann \& M. Gratzl. 1992. The light chain of tetanus toxin inhibits calcium dependent vasopressin release from permeabilized nerve endings. Neurosci. 46: 489-493.

54. Stecher, B., J. J. H. Hens, U. Weller, M. Gratzl, W. H. Gispen \& P. N. E. De Graan. 1992. Noradrenaline release from permeabilized synaptosomes is inhibited by the light chain of tetanus toxin. FEBS Lett. 312: 192-194.

55. Stecher, B., G. Ahnert-Hilger, U. Weller, T. P. Kammer \& M. Gratzl. 1992. Amylase release from streptolysin $\mathrm{O}$ permeabilized pancreatic acinar cells. Effects of calcium, GTPyS, cAMP, tetanus toxin and botulinum A toxin. Biochem. J. 283: 899-904.

56. Blasi, J., E. R. Chapman, E. Link, T. Binz, S. Yamasaki, P. De Camilli, T. C. Südhof, H. NIEMANN \& R. JAHN. 1993. Botulinum neurotoxin A selectively cleaves the synaptic protein SNAP-25. Nature 365: 160-163.

57. Schiavo, G., O. Rossetto, S. Catsicas, P. Polverino de Laureto, B. R. DasGupta, F. BENFENATI \& C. MONTECUCCO. 1993. Identification of the nerve terminal targets of botulinum neurotoxin serotypes A, D, and E. J. Biol. Chem. 268: 1-4.

58. Blasi, J., E. R. Chapman, S. Yamasaki, T. Binz, H. Niemann \& R. Jahn. 1983. Botu- 
linum neurotoxin $\mathrm{C} 1$ blocks neurotransmitter release by means of cleaving HPC1/syntaxin. EMBO J. 12: 4827-4828.

59. Link, E., L. Edelmann, J. H. Chou, T. Binz, S. Yamasaki, U. Eisel, M. Baumert, T. C. SÜdHOF, H. NiemanN \& R. JAHN. 1992. Tetanus toxin action: Inhibition of neurotransmitter release linked to synaptobrevin proteolysis. Biochem. Biophys. Res. Commun. 189: 1017-1023.

60. Schiavo, G., B. Poulain, O. Rossetto, F. Benfenati, L. Tauc \& C. Montecucco. 1992. Tetanus toxin is a zinc protein and its inhibition of neurotransmitter release and protease activity depends on zinc. EMBO J. 11: 3577-3583.

61. Schiavo, G., F. Benfenati, B. Poulain, O. Rossetto, P. P. de Laureto, B. R. DasGupta \& C. Montecucco. 1992. Tetanus and botulinum-B neurotoxins block neurotransmitter release by proteolytic cleavage of synaptobrevin. Nature 359: 832-835.

62. Schiavo, G., C. C. Shone, O. Rossetto, F. C. G. Alexander \& C. Montecucco. 1993. Botulinum neurotoxin serotype $\mathrm{F}$ is a zinc endopeptidase specific for VAMP/synaptobrevin. J. Biol. Chem. 268: 11516-11519.

63. Dayanithi, G., B. Stecher, B. Höhne-Zell, S. Yamasaki, T. Binz, U. Weller, H. Niemann \& M. Gratzl. 1994. Exploring the functional domain and the target of the tetanus toxin light chain in neurohypophysial terminals. Neuroscience 58: 423-431.

64. Höhne-Zell, B., B. Stecher \& M. Gratzl. 1993. Functional characterization of the catalytic site of the tetanus toxin light chain using permeabilized adrenal chromaffin cells. FEBS Lett. 336: $175-180$.

65. Baumert, M., K. Takei, J, Hartinger, P. M. Burger, G. Fischer von Mollard, P. R. Maycox, P. De Camilli \& R. JahN. 1990. P29: A novel tyrosine-phosphorylated membrane protein present in small clear vesicles of neurons and endocrine cells. J. Cell Biol. 110: 1285-1294.

66. Matteoli, M., F. Navone, C. Haimann, P. L. Cameron, M. Solimena \& P. De Camilli. 1989. Secretory organelles of neurons and their relationship to organelles of other cells. Cell Biol. Int. Rep. 13: 981-992.

67. NiemanN, H. 1991. Sourcebook of bacterial protein toxins. Molecular biology of clostridial neurotoxins. J. E. Alouf \& J. H. Freer, Eds.: 299-344. Academic Press. New York.

68. Jongeneel, C. V., J. Bouvier \& A. Bairoch. 1989. A unique signature identifies a family of zinc-dependent metallopeptidases. FEBS Lett. 242: 211-214.

69. Wright, J. F., M. Pernollet, A. Reboul, C. Aude \& M. G. Colomb. 1992. Identification and partial characterization of a low affinity metal-binding site in the light chain of tetanus toxin. J. Biol. Chem. 267: 9053-9058.

70. Littleton, J. T., M. Stern, K. Schulze, M. Perin \& H. J. Bellen. 1993. Mutational analysis of Drosphila synaptotagmin demonstrates its essential role in $\mathrm{Ca2}$-activated neurotransmitter release. Cell 74: 1125-1134.

71. Diantonio, A., K. D. Parfitt \& T. L. Schwarz. 1993. Synaptic transmission persists in synaptotagmin mutants of Drosophila. Cell 73: 1281-1290.

72. Nonet, M. L., K. Grundahl, B. J. Meyer \& J. B. Rand. 1993. Synaptic function is impaired but not eliminated in $C$. elegans mutants lacking synaptotagmin. Cell 73: 1291-1305.

73. Shojt-Kasal, Y., A. Yoshida, K. Sato, T. Hoshino, A. Ogura, S. Kondo, Y. Fujimoto, R. Kuwahara, R. Kato \& M. Takahashi. 1992. Neurotransmitter release from synaptotagmin-deficient clonal variants of $\mathrm{PC} 12$ cells. Science 256: 1820-1822.

74. Oyler, G. A., G. A. Higgins, R. A. Hart, E. Battenberg, M. Billingsley, F. E. BLOOM \& M. C. WILSON. 1989. The identification of a novel synaptosomal-associated protein, SNAP-25, differentially expressed by neuronal subpopulations. J. Cell Biol. 109: 3039-3052.

75. Elferink, L. A., W. S. Trimble \& R. H. Scheller. 1989. Two vesicle-associated membrane protein genes are differentially expressed in the rat central nervous system. J. Biol. Chem. 264: 11061-11064.

76. Geppert, M., B. T. Archer III \& T. C. Südhof. 1991. Synaptotagmin II. A novel differentially distributed form of synaptotagmin. J. Biol. Chem. 266: 13548-13552.

77. Trimble, W. S., T. S. Gray, L. A. Elferink, M. C. Wilson \& R. H. Scheller. 1990. 
Distinct patterns of expression of two VAMP genes within the rat brain. J. Neurosci. 10: $1380-1387$.

78. Wendland, B., K. G. Miller, J. Schilling \& R. H. Scheller. 1991. Differential expression of the p65 gene family. Neuron 6: 993-1007.

79. Bergmann, M., G. Lahr, A. Mayerhofer \& M. Gratzl. 1991. Expression of synaptophysin during the prenatal development of the rat spinal cord: Correlation with basic differentiation processes of neurons. Neurosci. 42: 569-582.

80. Ovtscharoff, W., M. Bergmann, B. Marquezze-Pouey, P. Knaus, H. Betz, D. Grabs, I. Reisert \& M. GrATZL. 1993. Ontogeny of synaptophysin and synaptoporin expression in the central nervous system: Differential expression in striatal neurons and their afferents during development. Dev. Brain. Res. 72: 219-225.

81. Bergmann, M., T. Schuster, D. Grabs, B. Marquezze-Pouey, H. Betz, H. Traurig, A. MAYeRhofer \& M. GRATZL. 1993. Synaptophysin and synaptoporin expression in the developing rat olfactory system. Dev. Brain. Res. 74: 235-244.

82. Oyler, G. A., J. W. Polli, G. A. Higgins, M. C. Wilson \& M. L. Billingsley. 1992. Distribution and expression of SNAP-25 immunoreactivity in rat brain, rat PC-12 cells and human SMS-KCNR neuroblastoma cells. Dev. Brain Res. 65: 133-146. 